\author{
Olga Nosova \\ D.Sc.(Economics), Professor \\ V.N. Karazin Kharkiv National University \\ 4 Svobody Sq., 61022, Kharkiv, Ukraine \\ E-mail: olgano59@gmail.com, ORCID: https://orcid.org/0000-0002-5638-6294 \\ Tetiana Nosova \\ Ph.D.(Economics), Associate Professor \\ V.N. Karazin Kharkiv National University \\ 4 Svobody Sq., 61022, Kharkiv, Ukraine \\ E-mail: tasya.n@gmail.com, ORCID: https://orcid.org/0000-0003-1757-4505
}

\title{
BUSINESS RELATIONS UNDER TRANSFORMATION INFLUENCES
}

The article aims to study and analyze the influence of transformation on business relations in East European countries. It includes revealing the essence of the transformation change, formal rules, informal constraints and enforcement characteristics. Literature review suggests that political and socioeconomic changes can affect transformation reforms in the framework of speeding them up. The process of convergence of the new institutional economy and the evolutionary economy theories demonstrate confirms the existence of common theoretical foundations. They include recognition of the existence of limits of rational behavior of economic entities, unpredictability, and irreversibility of business decision-making process. Institutional transformation assumes a complex process, where mechanical copying and transferring institutions do not provide quantitative changes, and need the development of formal rules and informal institutions, law enforcement mechanism, as well as consciousness and mental characteristics of the population. The content of the modern institutional system of transformation, including the institutional-legal, institutional-economic and institutional-technological systems, is presented. The systematization of classification features is carried out: content, the main tasks and results of the functioning of the institutional transformation subsystems. The effectiveness of the present system is considered, based on revealing the relationship and the influence of all its subsystems. Transformation changes affect business environment, and result in foundation of a stronger legal framework and a system of property rights, decreasing bureaucracy, and enhancing competition. The success of any efforts to weaken the influence of ineffective institutions will depend primarily on whether East European countries' present-day facade institutions can be replaced with institutions that are robust and independent. Application of the interdisciplinary approach promotes an in-depth study the drivers of transformation reforms, and proposes scenarios for future development of East European countries.

Keywords: transformation, business relations, institutions, formal and informal rules.

JEL Classification: M20, M21, P48.

Statement of the problem. The purpose of this article is to study the effect of transformation on business relations in East European countries. To solve the study problem of the newly emerging institutional system in East European countries we will consider the market system in the form of the interaction of its constituent subsystems and the processes occurring within it. Firstly, we will investigate the functioning system in East European countries. Secondly, we will define the main directions, possible channels, methods of influence on the system with the aim of its transformation into the market one. Transformation of post-socialist institutions into market institutions is an important task of transition countries. A transformable system contains the rudiments of the old system, signs of an emerging deformed system, as well as elements of a market system.

Formation of a market economy in the countries of Eastern Europe is based on the creation and functioning of an effective system of institutions. Transition to a new institutional system involves not only modifying existing institutions, redistributing functions between them, but also creating new types of them. Former system of institutions limited the possibilities of efficient operation of the enterprises and often led to the adoption of deliberately meaningless investment decisions.

Study of the issues of transformation change is one of the most important questions of economic theory that determines economic development of the countries. The problem of

\footnotetext{
${ }^{\odot}$ Nosova O., Nosova T., 2020
} 
transformation change in the countries of Eastern Europe is reflected in the works of those scientists, who applied multidisciplinary approaches to understand complexity and instability of economy. An increasing unpredictability of socio-economic processes requires extending the traditional approaches, and promoting alternative institutional and evolutionary methodologies to provide better socio-economic regulation.

Application of comparative economics methods used for comparison of economic systems, analysis and systematization the best practices of transformation could be used for assessment and forecasting various scenarios of the development of the countries in transition.

At present, scientists argue that the process of convergence of theories of a new institutional economy and the evolutionary economy, are conditioned by the existence of common theoretical foundations: recognition of the existence of limits of rational behavior of economic agents, unpredictability, and irreversibility of business decision-making process, and interdependence routines. Expansion of the study object of the evolutionary economy by incorporating in it innovation change, and the study of organizational issues and organizational choice of the agents in a dynamic process of competition of rival firms driven by innovation and selection from other industries, realized by the new institutional economy, contributes to the convergence of both approaches.

Analysis of recent studies and publications. In the economic literature, the question of the business environment formation is reflected in a number of scientific publications. The study of business environment deals with the analysis of economic agents behavior under predetermined conditions, but also consider the role, influence and directions for improving such conditions (Кузьмина, Бендукидзе, \& Юдкевиич, 2006). Skorobogatov (2006) emphasizes informal, formal and local rules, which act as a link between uncertainty and time-ordered changes in the phases of business activity. Malevich (2002) uses a universal approach for transformational and transactional costs. Examination of these works testifies the relevance and applied character of a number of studies investigating and trying to explain certain atypical problems: the spread of informal institutions, the emergence of institutional anomalies, mismanagement, self-interested opportunism, and other sources of economic stagnation.

The transformation process includes transformation change, which involves a shift in the system of formal and informal norms, rules and traditions resulting in changing strategy of organization. Glinkina (2010) underlines four theoretical approaches to transformation: theological approach, absolutized evolutionism, genetic approach, transition by means of borrowing institutions, existing in the most developed Western countries. The author confirms that in real life borrowing was either formal or was supported by related mechanisms of coercion to efficient performance (in the countries of Central and Eastern Europe).

It should be noted that there are differences in the implementation of reforms, caused by unequal starting conditions, speed and sequence. In order to clarify the basic directions of transformation and to consider principal approaches scientists should focus on the main points of view on this issue. North (1989) argues that the interdependence of political and economic institutions is examined against premises in neoclassical theories of economics, which maintain that population and savings are the principal determinants of economic growth. Western scholars apply the factors of economic growth in the analysis of the successful reforms in Eastern European countries.

Nabli \& Nugent (1989) analyze the determinants and effects of institutional change in the context of economic development. Having depicted the modern approaches for transformation, let us consider the economic performance indicators of the countries. Some scientists associate overcoming the consequences of the global financial crisis with the end of the neoliberal era and the restoration of a fair, equitable and stable democratic economic order. How fully this opportunity will be realized depends on the decisions made by politicians and economists. In the event of a continuation of the recession and its protracted nature, the hegemony of neoliberal financial capital will destroy effects of social state institutions instead of its recovery. If this does not happen, then normal business development will accompany economic growth over a long run.

Furceri \& Zdzienicka (2011) stress the necessity of an effective mechanism for regulating relations between the leading world countries which should take into account private interests of the international actors of the world capitalist market. The authors assess the impact of the financial crisis on the development of 11 European countries. The received results reflect a reduction in the industrial output by 12-17 percent in the long run. 
Stable development of the global economy is one of the most important conditions for the success of transformational change in Eastern Europe. Comparison of performance indicators of functioning institutions, the state of social and demographic structure of the society indicates the existence of the differences in the rate of market reforms in Eastern European countries. Pre-crisis economic development indicators of the countries of Central and Eastern Europe (CEE) demonstrate the achievement of a state of a stable level of development. Data analysis of the integral indicator for assessing the advancement of market reforms and the socioeconomic development of CEE, developed by the Institute of International Economics and Political Studies (IEPS), indicates that from point of view of system transformation Slovenia, Poland and the Czech Republic are among the top three leaders.

Such countries as Hungary and Slovakia follow the leaders in the subgroup of countries under consideration. The accession of ten CEE countries to the European Union was accompanied by an accelerated implementation of institutional reforms. The creation of law enforcement mechanism, property rights protection, the development of political and social institutions of a democratic society were the basic legal reforms which created the foundation for further system transformation. Labor productivity growth was identified as the main driver of economic growth in CEE countries. The growth of labor productivity was 50\%-70\% of the average GDP growth rate in the period from 1995 to 2004 (Schadler et al., 2006).

It should be noted the increase in per capita GDP in 2008, the average GDP growth rate in 1989-2009 in the CEE countries during the period of reform. The onset of the global financial crisis was accompanied by deterioration of the economic indicators, including the increase in the ratio of public debt to GDP (See table 1).

Country Economic Indicators in Central Eastern Europe

Table 1

\begin{tabular}{|c|c|c|c|c|c|}
\hline Country & $\begin{array}{c}\text { GDP per } \\
\text { capita 2008 } \\
\text { (USD) }\end{array}$ & $\begin{array}{c}\text { Average GDP } \\
\text { growth 1989- } \\
2009\end{array}$ & $\begin{array}{c}\text { GDP per } \\
\text { capita in } \\
1989(\text { USD) }\end{array}$ & $\begin{array}{c}\text { Ratio of public } \\
\text { debt to GDP in } \\
2010(\%)\end{array}$ & $\begin{array}{c}\text { Ratio of } \\
\text { accumulated FDI } \\
\text { funds to GDP in } \\
2008(\%)\end{array}$ \\
\hline Czech Republic & 25398 & 1,58 & 7590 & 38,5 & 53,2 \\
\hline Hungary & 15326 & 1,19 & 3027 & 80,2 & 41,1 \\
\hline Poland & 13839 & 2,81 & 2147 & 55 & 31,1 \\
\hline Slovakia & 18249 & 2,37 & 3351 & 41 & 49,2 \\
\hline
\end{tabular}

Source: (Eurostat)

J. Kornai (2006) provides a definition of institutional transformation and considers it as a process connected with urbanization, industrialization and commercialization. He notes such basic transformation institutions as financial system, labor force, market mechanisms usage, private property rights and regulations.

Scientists have different views on the formation and pace of institutional reforms. Tridico (2011) stressed that Central European countries performed much better than other transition economies. The author has verified that countries having a better institutional framework enhanced the human development indicators. Institutional development depends on political, social, economic performance of each country. Economic progress in transformation improves economic growth, effects peoples well-being, create broad business opportunities. CEE countries joining the European Union (EU) was accompanied by the institutional system foundation in May 2004, and for Bulgaria and Romania - in 2007. The main Copenhagen criteria defined the following requirements: guaranteeing the presence of democracy stable political institutions, market economy formation, domestic legislation harmonization based on the principles of European law for potential EU members.

During the period from 1995 to 2003 per capita GDP of 8 new EU members, along with productivity and real per capita consumption, increased at a higher rate than in EU countries. The growth rate of labor productivity of new members was 4 times the rate of the old EU members (Kornai, 2006). Czech Republic, Poland and Hungary make up 63 per cent of the whole GDP of the newly entered members of the European Union. These countries are among ten Central European 
states that reached progress in terms of reforms, market economy and attractive investment climate for foreign investors (Transition Report, 2001).

Considering the experience of transformation in Poland, one may noticea systemic nature of reforms and their sequencing. Adoption of legal acts on business activities, privatization, combating unfair competition, bankruptcy, as well as the laws "On banks", "On antitrust activities", "On foreign exchange transactions", etc. created the basis for a legal system formation in Poland. The legal environment create basis for formal and informal norms, rules, regulations in the society. The analysis of the mutual effect of legal norms on the business relations in Poland demonstrates that informal and formal norms do not adequately reflect each other. This is explained by that a number of formal norms are not well-known. Constant updating or the absence of a number of legal acts impede moral upbringing and legal education. Human rights protection in court is complex and requires significant financial resources and a considerable period of time.

Moreover, the discrepancy between various legal acts one could take into account, makes legal decisions unpredictable (Lissowska, 2008). Using enforcement mechanism to maintain the institutional order in a transforming system, as well as to ensure compliance with institutional norms, rules and traditions is an important factor in achieving stable state. Ineffectiveness of coercion mechanism is a consequence of the legal system imperfection. Functional institutions demonstrate low control level, asymmetry of information, business groups interests lobbying. Contradiction between business elites for obtaining additional rent resulted in corporate conflicts appearance. Conflict resolution could be provided on the basis of compliance with the rules and the removal of certain groups privileges.

Poland has proved to be the most resilient to the consequences of crisis 2008-2009.Country had positive GDP growth at the period when the European Union used to have negative growth. The growth rate was not equal in all Polish regions. Unemployment rate in Poland was substantially higher than in the European Union28 average throughout the early 2000s, although it started to come down sharply from the middle of the decade, and by the time of the financial crisis, it was more or less on the same level. In the post-crisis period, Poland's strong economic performance manifested itself in the fact that unemployment rate is now lower than the average across the EU28. Throughout 2005-2014, the ratio of public investment in GDP within the low income Member States exceeded that in the low growth Member States. Furthermore, the public investment-to-GDP ratio in low growth Member States started falling in 2010 and was below its 2000 level. This slowdown occurred in the flow of public investment (from 4 per cent of GDP in 2007 to just above 2 per cent in 2015). Scientists consider that in case this trend continues, it will result in the potential to damage long-term economic growth (Romisch et. al., 2017).

Experts considered that the balance in the global economy, formed by the beginning of 2012 , was unstable. CEO's survey of the largest companies in the world showed that approximately $38 \%$ of executives from Western Europe and $42 \%$ from Central Eastern Europe are confident in the longterm growth of their business (Гайдаев \& Ладыгин, 2012).

Rekine \& Walsh (1998) argued that deep integration into the European Union stimulate foreign capital inflow and attraction of foreign experts to Poland. Total volume of foreign capital from the European Union attracted to Poland reached $75 \%$.Scientists believe that further deepening cooperation within Europe in the single market functioning will produce one percent increase in growth rate. Hoekman \& Djankov (2001) conducted an econometric study that revealed the existence of a relationship between export positions and intra-company trade of the countries of Central and Eastern Europe with the European Union. Development of the economies of the Czech Republic, Slovakia, Poland and Slovenia depends on export earnings from the countries of the European Union. High rates of export growth per capita were an important indicator of the success of economic reforms. Growing exports contributed to the strengthening of the real sector of the economies of Germany and Italy. In transformation research by Dritsaki et al. (2004), authors study dependence between foreign trade and economic growth. They make conclusion that trade balance improvement promote and stimulates innovations in R\&D.

The study and analysis of the Central European countries experiences illustrate the consistent nature of reforms implementation, including institutions foundation, property rights definition, institutional infrastructure formation, and the establishment of interconnections between all institutions. Djankov (2016) provided a definition of challenges of transitional economics. He included the factors of economic growth in transition countries are the following: attracting and retaining 
people as the labor force, catching up on innovation, and developing financial institutions, supporting of green economy. Central and Eastern European countries meet these challenges for obtaining and using new knowledge, rapid absorption of the types of European institutions, adaptation of new rules and norms, and political structures settings.

Statement of the objectives of the article. The article studies the impact of transformation on business relations in East European countries. In order to solve the study problem, we use interdisciplinary approach for the analysis of transformation in Central East European countries. Institutional approach included new institutional and evolutional analysis applied for the assessment of business relations peculiarities. Comparative economics methods applied for comparison of successes and failures of transition reforms in Central European countries.

Presentation of the basic material. The implementation of reforms in CEE countries confirms the importance of the development of an effective institutional system. We consider the notion of transformation in qualitative terms of change from one state to another, as serious, large-scale, and deep alterations. The use of the category of transformation involves the application of two new criteria: qualitative change, as well as a balance of changes and continuity.

The latter makes the transformation in principle reversible, although in fact the provision of such reversibility requires very serious justification. The process of adopting decrees or legislative acts needs a transformational period for establishing social and organizational capital. Economic actors should be actively involved in the implementation of reforms and act as driving forces for their implementation. Otherwise, reforms based on bribery and threats will not be effective and will not lead to a change in behavior in society, which means the absence of transformation (Stiglitz, 1999).

Akaev et al. (2016) examine the results of almost 25-year-long transformation of these countries, and define three types of transformation. First, there were transformations on the ideological level. Transformations of the second type were purely economic. The third type is described as institutional (including structural and financial) transformation. The authors emphasize the important reasons for modest economic performance in the post-Soviet space. The new states ignored and did not use the principles of regional policy and regional modernization in their statebuilding practice, and it resulted in growing polarization of income levels in different regions as the dominant trend of rising economic inequality. Mitra \& Yemtsov (2006) argue that the process of transition to a market economy is not complete and that further evolution of inequality will depend both on transition-related factors. They are the evolution of the education premium, a bias in the investment climate against new private sector firms, which are important vehicles of job creation and regional impediments to mobility of goods and labor, as well as increasingly other factors, such as technological change and globalization. Consider the modern institutional system in the following form, which includes institutional legal subsystem, institutional economic subsystem and institutional technological subsystem (See table 2). The system efficiency depends on the effectiveness of all the subsystems, including those, mentioned above.

Table 2

Institutional system transformation

\begin{tabular}{|l|l|l|l|}
\hline \multicolumn{1}{|c|}{ Subsystem } & \multicolumn{1}{|c|}{ Content } & \multicolumn{1}{c|}{ Basic Tasks } & \multicolumn{1}{c|}{ Results } \\
\hline $\begin{array}{l}\text { Institutional legal } \\
\text { subsystem }\end{array}$ & $\begin{array}{l}\text { Legislation, contracts, legal } \\
\text { institutions, informal norms }\end{array}$ & $\begin{array}{l}\text { Setting rules, } \\
\text { guaranteeing stability }\end{array}$ & $\begin{array}{l}\text { Transaction costs } \\
\text { minimization }\end{array}$ \\
\hline $\begin{array}{l}\text { Institutional economic } \\
\text { subsystem }\end{array}$ & $\begin{array}{l}\text { Market institutions, infrastructure, } \\
\text { institutions, business environment }\end{array}$ & $\begin{array}{l}\text { Optimization ofmarket } \\
\text { functions }\end{array}$ & Profit maximization \\
\hline $\begin{array}{l}\text { Institutional } \\
\text { technological } \\
\text { subsystem }\end{array}$ & $\begin{array}{l}\text { Academic institutions, higher } \\
\text { education institutions, consulting } \\
\text { firms, scientific and industrial } \\
\text { associations }\end{array}$ & $\begin{array}{l}\text { Elaboration and } \\
\text { application R\&D }\end{array}$ & $\begin{array}{l}\text { Technological effects } \\
\text { maximization }\end{array}$ \\
\hline
\end{tabular}

Source: authors' approach.

Modern institutional system is still in a state of formation. Imperfection of the legal system manifests itself in ineffectiveness of coercion mechanism, lack of control, asymmetry of information, and lobbying of the interests of certain business groups in order to obtain rent. Compliance with legal norms reflects the intensification of the activities of various interest groups stimulates the implementation of favorable changes and leads to privileges elimination. 
Destruction of formal regulators, the prevalence of informal rules, implicit contracts and quasipersonified transactions were accompanied by an increase of corruption. Yasin \& Snegovaya (2010) indicate that if democratic institutions are not rooted, punitive measures to fight corruption will prevail. It can grow even more, including merging bureaucratic and oligarchic client networks with corrupt connections with corrupt clans. Relations between transnational companies regarding compliance with the rules of corporate ethics, uncertainty in the use of the principles of the precedent system and the regulatory system in resolving a number of legal issues remain an unresolved problem. Simple transfer or mechanical copying of western types of institutions is not effective.

The predominance of negative features in the newly emerging institutional system manifests itself in the existence of conflicting interests between various business groups, using forms of lobbying interests, applying diverse schemes for receiving rent, removing part of financial resources from the real sector into a shadow turnover, completely losing or discrediting the concept of moral values etc.

The inefficiency of the mechanism of coercion stated in the failure of the legal system to perform the regulatory function, through which there is an impact on social relations through regulation and on the organization of the behavior of individuals. The law fulfilling the educational function in society provides that knowledge and application of legal norms and laws create a legal basis for the development of cooperative relations with business.

During the transformation period, the crucial importance should be given to the timely and highquality implementation by law enforcement agencies of their functions and duties. The main functions are supervision, control and coordination of relations in society. The problem is not only in the redistribution of the functions of any institutions, but also in their transformation, as well as the creation of new types of missing institutions.

New institutional norms, rules in society should be clearly defined, predictable, ensure trust, transparency, continuity of relations between agents. Analysis of the transformational changes in the countries of Central Eastern Europe (CEE) shows that the basis for the successful implementation of the reforms was a system approach, continuity, and complexity of reforms.

The use of Western institutions by CEE countries, integration into the European Union contributed to the adoption of and compliance with international legal acts, rules and regulations at the state level, as well as their dissemination by all segments of the population. Reducing the imbalance of the economy contributed to the achievement of macroeconomic stabilization by countries: small amount of the budget deficit, reduction of public debt and inflation decrease.

Conducting institutional changes led to the observance of legality, the maintenance of legal regulation in society and the increase of trust in them. At the initial stage of the reform, there was a need to create institutions that define the rules of conduct, which serve as a mechanism for controlling the economic behavior of subjects. The establishment of new institutions is aimed at the development of the domestic market, its infrastructure, as well as the provision of various types of services. (Nosova, 2017)

Across the European Union, annual real GDP growth rates vary widely between almost 4 percent and -0.5 percent. By and large, the highest GDP growth among European Union was inCEE countries: with average annual real GDP growth rates of between 3 percent and 4 percent, the economies of the Slovak Republic, Romania, Poland, Lithuania, Estonia, Latvia, and Bulgaria expanded the most. By contrast, the Greek economy contracted by around 0.5 percent annually. The GDP of the European Union as a whole also grew by on average 1.4 percent per annum. Furthermore, except of Luxembourg, Italy and Greece, average annual labor productivity growth rates were generally positive and the highest - with more than 3 percent per annum - in Romania, Lithuania and Latvia (Stehrer \& Leitner, 2019).

Reforms in post-Soviet countries, including Poland, point at the important role of creating an effective institutional system for successful transformational reforms. Transformation is considered in qualitative terms as serious, large-scale, profound changes. Applying the category of transformation involves the inclusion of two new operational criteria: qualitative change, as well as a balance of changes and continuity. In principle, the latter makes transformation reversible, although in fact the provision of such reversibility requires very serious grounds.

Analysis of post-crisis processes in the most post-socialist countries indicates the predominance of the forms of simulation of market infrastructure elements, the use of behavioral 
stereotypes inherent in the command system, copying forms, elements of the structure of the market economy of industrialized countries.

The state does not possess the necessary features of a special economic entity that personifies the whole of society. At the same time, the subjective interest of society is expressed in the need of society to ensure expanded reproduction of its own potential. Consequently, institutional processes are contradictory, non-systemic. Transforming economy of the post-Soviet countries has the properties of heterogeneity, characterized by the features of multifactor models.

At the initial stage of economic reforms, the state played a passive role, which was the reason for the low development of the legal foundations of private property and market institutions and market infrastructure in most countries of Eastern Europe. The weak development of the institutions of entrepreneurship and private property, competition, social partnership, whose rights would be protected and guaranteed by the state, was a brake on privatization and prevented the emergence of real owners in a competitive market environment.

The use of traditional, sustainable stereotypical forms of business behavior, including the old set of "routines," ensured the continuity of the old forms of behavior of the old institutional system. Such a process led to the formation of the forms of forced behavior of investment subjects: spread of mutual banking defaults, failure to meet specific obligations, passive nature of investment, transfer of funds to offshore zones, etc.

Developing countries try to tackle the idea of efficient public administration, while avoiding new destabilization and violence (North et al., 2012). The authors highlight the issue of rent distribution in the countries with limited access to power and resources. It was argued that the receipt of rent can both hinder and promote development. A positive effect was observed when, through the redistribution of income, business was stimulated, and real assets created. A negative result was obtained, where this process provided a relationship of political dependence for business.

Another factor in improving the effectiveness of limited access to resources is the gradual transformation of personalized relations between elites. Interdependence among representatives of impersonal institutions impedes business communications. Such organizations are closely associated with the government, but they are more durable than their leaders are. Researchers argue that the general rules for the elite should be formed, and it is the base for emergence of universal rules for the whole society.

Conclusion. The evaluation of the numerous theoretical approaches of transformation proves complexity and incompleteness of the transformation period in a number of East European countries and the necessity of search for new economic methods and forms to speed up reforms in these countries.

The content of the modern institutional system of transformation, including the institutionallegal, institutional-economic and institutional-technological systems, is presented. The systematization of classification features is carried out: content, the main tasks and results of the functioning of the institutional transformation subsystems. The effectiveness of the present system is considered on the example of revealing the relationship and the influence of all its subsystems.

The study of the underlying processes and experiences in Central East European countries make it possible to identify development trends for the post-Soviet countries. Successful implementation of institutional reforms contributes forreducing the economic imbalances, transferring from illegal methods of enrichment, achieving qualitative changes of formaland informal rules and institutions and creating competitive business environment.

\section{Література}

1. Кузьмина Я.И., Бендукидзе К.А., Юдкевиич М.М. Курс институциональной экономики: институты, сети, трансакционные издержки, контракты. М: ГУ-ВШЭ, 2006. 444 с.

2. Скоробогатов А. Институты как фрактор порядка и источник хаоса. Вопросы экономики, 2006. № 8. С. 102-118.

3. Malevich Y. Institutional equilibrium. Ecological Survey. 2002. №. 2. P. 276-300.

4. Glinkina S. Post-communist transformations: multilevel analysis methodology. Ekonomski pregled. 2010. Vol. 61, № 11. P. 699-716.

5. North D.C. Institutions and Economic Growth. An Historical Introduction. World Development. 1989. Vol. 17, Is. 9. P.1319-1332. 512 p.

6. Nabli M.K., Nugent J.B. The New Institutional Economics and its applicability to development. World Development. 1989. Vol. 17, Is. 9. P. 1333-1347. 
7. Furceri D., Zdzienicka A. How Costly are Debt Crises? IMF Working Papers. 2011. № 11/280. P. 1-29. URL: https://ssrn.com/abstract=1971431.

8. Schadler S., Mody S., Abiad A., Leigh D. Growth in the Central and Eastern European countries of the European Union. IMF Occasional paper. 2006. № 252. Washington D.C.: International Monetary Fund. URL: https://www.imf.org/en/Publications/Occasional-Papers/Issues/2016/12/31/Growth-in-the-Central-and-EasternEuropean-Countries-of-the-European-Union-19210.

9. Eurostat. URL: http://epp.eurostat.ec.europa.eu/portal/page/portal/eurostat/home/.

10. Kornai J. Great transformation of the Central - East Europe: success and disappointment. Economics of Transition. 2006. Vol. 14 (2). P. 207-244. DOI: https://doi.org/10.1111/i.1468-0351.2006.00252.x.

11. Tridico P. Institutions, Human Development and Economic Growth in Transition Economies. London: Palgrave Macmillan, 2011. DOI: https://doi.org/10.1057/9780230313880.

12. Transition Report, 2001. London: EBRD. URL: https://www.ebrd.com/publications/transition-report-2001-english.pdf.

13. Lissowska M. Institutions for market economy. The case of Poland. Warszawa: Wydawnictwo C.H. Beck, 2008. 271 p.

14. Romisch R.,Brown A., Gardiner B., Stenning J. Economic challenges of lagging regions i: fiscal and macroeconomic environment. WIIW Research Report. 2017. № 421. URL: https://www.econstor.eu/handle/10419/204193.

15. Гайдаев В., Ладыгин Д. Мировые лидеры обращаются к кадрам. Коммерсант. 2012. URL: http://www.kommersant.ru/doc/1858101.

16. Rekine A., Walsh P.P. European trade and foreign direct investment. U-Shaping industrial output in Central and Eastern Europe: theory and evidence. IMF Working Paper. 1998. № 98/150. URL: https://econpapers.repec.org/paper/imfimfwpa/98 2f150.htm.

17. Hoekman B., Djankov S. Intra-industry trade, foreign direct investment, and the orientation of Eastern European exports. World Bank Policy Research Working Paper. 2001. № 1652. DOI: https://doi.org/10.1596/1813-9450-1652.

18. Dritsaki M., Dritsaki C., Adamapolous A. A causal relationship between trade, foreign direct investment and economic growth for Greece. American Journal of Applied Sciences. 2004. Vol. 1 (3). P. 230-235.

19. Djankov S. Challenges to Eastern Europe's growth. Background paper for the panel on reinvigorating growth, Competitiveness and investment, EBRD Conference, Budapest, 10 October 2016.

20. Stiglitz, J. E. Whither Reform. 10 Years of transition. keynote address. Annual Bank Conference on Development Economics. Washington: D.C., 1999. P. 105

21. Akaev A. A., Ichkitidze Y. R., Sarygulov A. I., Sokolov, V. N. Post-socialist transformation of central and eastern europe at the turn of the century: regional development and economic inequality. R-Economy. 2016. Vol. 2, Is. 3. P. 279-289. DOI: doi 10.15826/recon.2016.2.3.025.

22. Mitra P., Yemtsov R. Increasing inequality in transition economies: is there more to come? World Bank Policy Research Working Paper. 2006. №4007. URL: http://documents.worldbank.org/curated/en/733471468282883074/ncreasinginequality-in-transition-economies-is-there-more-to-come.

23. Ясин Е., Снеговая М. Институциональные проблемы в России в глобальном контексте. Проблемы экономики, 2010. № 1. С. 123-139.

24. Nosova O. The impact of globalization on financial institutions' development. Europa Regionum. 2017. T. XXX, № 1. P. 99-119.

25. Stehrer R., Leitner S. M. Demographic challenges for labour supply and growth. Research Report. 2019. № 439. URL: https://wiiw.ac.at/demographic-challenges-for-labour-supply-and-growth-dlp-4868.pdf.

26. North D., Wallis J., Webb S., Weingast B. In the shadow of violence: politics, economics and the problems of development / Eds. D. North, J. Wallis, S. Webb, B. Weingast. Cambridge: Cambridge University Press, 2012. DOI: https://doi.org/10.1017/CBO9781139013611.

\section{References}

1. Kuzmina, Y. I., Bendukidze, K.Y., Yudkevich, M. M. (2006). The course of institutional economics. institutes, networks, transaction costs. contracts. Moscow: Publisher House of the Higher School of Economics. (in Russian)

2. Skorobogatov, A. (2006). Institutions as a factor of order and as a source of chaos. Questions of Economics, 8, 102-118. (in Russian)

3. Malevich, Y. (2002). Institutional equilibrium. Ecological Survey, 2, 276-300.

4. Glinkina, S. (2010). Post-communist transformations: multilevel analysis methodology. Ekonomski pregled, 61(11), 699-716.

5. North, D.C. (1989). Institutions and economic growth. An historical introduction. World Development, 17(9), 1319-1332.

6. Nabli, M.K., Nugent, J.B. (1989). The new institutional economics and its applicability to development. World Development, 17(9), 1333-1347.

7. Furceri, D. and Zdzienicka, A. (2011). How Costly are Debt Crises? IMF Working Papers, 11/280, 1-29. Retrieved from https://ssrn.com/abstract=1971431.

8. Schadler, S., Mody, S., Abiad, A., Leigh, D. (2006). Growth in the Central and Eastern European countries of the European Union. IMF Occasional papers, 252, Washington D.C.: International Monetary Fund. Retrieved from https://www.imf.org/en/Publications/Occasional-Papers/lssues/2016/12/31/Growth-in-the-Centraland-Eastern-European-Countries-of-the-European-Union-19210. 
9. Eurostat. Retrieved from http://epp.eurostat.ec.europa.eu/portal/page/portal/eurostat/home/.

10. Kornai, J. (2006). Great Transformation of the Central - East Europe: success and disappointment. Economics of transition, 14(2), 207-244. doi: https://doi.org/10.1111/j.1468-0351.2006.00252.x.

11. Tridico, P. (2011). Institutions, Human Development and Economic Growth in Transition Economies. London: Palgrave Macmillan. doi: https://doi.org/10.1057/9780230313880.

12. Transition Report, 2001. London: EBRD. Retrieved from https://www.ebrd.com/publications/transitionreport-2001-english.pdf.

13. Lissowska, M. (2008). Institutions for market economy. The case of Poland. Warszawa: Wydawnictwo C.H. Beck.

14. Romisch, R., Brown, A., Gardiner, B., Stenning, J. (2017). Economic challenges of lagging regions i: fiscal and macroeconomic environment. WIIW Research Report, 421. Retrieved from https://www.econstor.eu/handle/10419/204193.

15. Gaydaev, V., Ladygin, D. (2012). World leaders put on cadres. Kommersant. Retrieved from http://www.kommersant.ru/doc/1858101. (in Russian)

16. Rekine, A., Walsh, P.P. (1998). European trade and foreign direct investment. U-Shaping industrial output in Central and Eastern Europe: theory and evidence. IMF Working Paper, 98/150. Retrieved from https://econpapers.repec.org/paper/imfimfwpa/98 2f150.htm.

17. Hoekman, B., Djankov, S. (2001). Intra-industry trade, foreign direct investment, and the orientation of Eastern European exports. World Bank Policy Research Working Paper, 1652. doi: https://doi.org/10.1596/18139450-1652.

18. Dritsaki, M., Dritsaki, C., Adamapolous, A. (2004). A causal relationship between trade, foreign direct investment and economic growth for Greece. American Journal of Applied Sciences, 1(3), 230-235.

19. Djankov, S. (2016). Challenges to Eastern Europe's growth. Background paper for the panel on reinvigorating growth, Competitiveness and investment, EBRD Conference, Budapest.

20. Stiglitz, J. E. (1999). Whither Reform. 10 years of transition. keynote address. Annual Bank Conference on Development Economics. Washington: D.C.

21. Akaev, A. A., Ichkitidze,Y. R., Sarygulov, A. I., Sokolov, V. N. (2016). Post-socialist transformation of Central and Eastern Europe at the Turn of the Century: Regional Development and Economic Inequality. $R$ Economy, 2(3), 279-289. doi: doi 10.15826/recon.2016.2.3.025.

22. Mitra, P., Yemtsov, R., (2006). Increasing inequality in transition economies: is there more to come? World Bank Policy Research Working Paper, 4007. Retrieved from http://documents.worldbank.org/curated/en733471468282883074/lncreasing-inequality-in-transition-economies-is-there-more-to-come.

23. Yasin, E., Snegovaya, M. (2010). Institutional problems of russia in the global context. Problems of Economics, 1, 123-139. (in Russian)

24. Nosova, O. (2017). The Impact of globalization on financial institutions' development. Europa Regionum, XXX(1), 99-119.

25. Stehrer, R., Leitner, S. M. (2019). Demographic challenges for labour supply and growth. Research Report, 439. Retrieved from https://wiiw.ac.at/demographic-challenges-for-labour-supply-and-growth-dlp-4868.pdf.

26. North, D., Wallis, J., Webb, S., Weingast, B. (Eds.). (2012). In the shadow of violence: politics, economics and the problems of development. Cambridge: Cambridge University Press. doi: https://doi.org/10.1017/CBO9781139013611.

\section{О.В. Носова}

доктор економічних наук, професор

Харківський національний університет імені В.Н. Каразіна майдан Свободи, 4, м. Харків, 61022, Україна

E-mail: olgano59@gmail.com, ORCID: https://orcid.org/0000-0002-5638-6294

Т.Ю. Носова

кандидат економічних наук, доцент

Харківський національний університет імені В.Н. Каразіна майдан Свободи, 4, м. Харків, 61022, Україна

E-mail: tasya.n@gmail.com, ORCID: https://orcid.org/0000-0003-1757-4505

\section{ВПЛИВ ТРАНСФОРМАЦІЇ НА БІЗНЕС-ВІДНОСИНИ}

Метою статті $є$ вивчення та аналіз впливу трансформації на ділові відносини в країнах Східної Європи. Стаття розкриває сутність трансформаційних змін, формальних і неформальних правил, обмежень і застосування примусових форм. Огляд літератури свідчить про те, що політичні та соціальноекономічні зміни впливають на швидкість проведення реформ в напрямку їх прискорення. Процес зближення теорій нової інституціональної та еволюційної економік підтверджує існування загальних 
теоретичних основ. До них відносяться визнання існування меж раціональної поведінки економічних суб'єктів, непередбачуваності і незворотності процесу прийняття ділових рішень. Інституційна трансформація передбачає складний процес, в якому механічне копіювання та перенесення інститутів не сприяє кількісним змінам і потребує розробки формальних правил і неформальних інститутів, застосування правових механізмів, свідомості та ментальних особливостей населення. Розглянуто зміст сучасної інституційної системи трансформації, що включає інституційно-правову, інституційно-економічну та інституційно-технологічну системи. Проведена систематизація класифікаційних ознак: зміст, основні завдання і результати функціонування підсистем інституційної системи трансформації. Ефективність діючої системи розглянута на базі виявлення впливу і взаємозв'язку всіх її підсистем. Трансформаційні зміни впливають на бізнес-середовище та призводять до зміцнення правової бази та системи прав власності, зниження бюрократії і посилення конкуренції. Успіх будь-яких зусиль з послаблення впливу неефективних інститутів залежить, перш за все, від того, наскільки швидко можна замінити існуючі державні інститути східноєвропейських країн на більш надійні і незалежні інститути. Застосування міждисциплінарного підходу сприяє поглибленому вивченню рушійних сил проведення реформ і може використовуватися для визначення сценаріїв майбутнього розвитку країн Східної Європи.

Ключові слова: трансформація, бізнес відносини, інститути, формальні і неформальні правила.

JEL Classification: M20, M21, P48.

О.В. Носова

доктор экономических наук, профессор Харьковский национальный университет имени В.Н. Каразина пл. Свободы, 4, г. Харьков, 61022, Украина

E-mail: olgano59@gmail.com, ORCID: https://orcid.org/0000-0002-5638-6294

Т.Ю. Носова

кандидат экономических наук, доцент

Харьковский национальный университет имени В.Н. Каразина

пл. Свободы, 4, г. Харьков, 61022, Украина

E-mail: tasya.n@gmail.com, ORCID: https://orcid.org/0000-0003-1757-4505

\section{ВЛИЯНИЕ ТРАНСФОРМАЦИИ НА БИЗНЕС-ОТНОШЕНИЯ}

Целью статьи является изучение и анализ влияния трансформациина деловые отношения в странах Восточной Европы. Статьяраскрывает сущность трансформационных изменений, формальных $и$ неформальных правил, ограничений и применение форм принуждения. Обзор литературы свидетельствует о том, что политические и социально-экономические изменения могут влиять на скорость проведения реформ в направлении их ускорения. Процесс сближения теорий новой институциональной и эволюционной экономик подтверждает существование общих теоретических основ. К ним относятся признание существования границ рационального поведения экономических субъектов, непредсказуемости и необратимости процесса принятия деловых решений. Институциональная трансформация предполагает сложный процесс, В котором механическое копирование и перенос институтов не приводит к количественным изменениям и нуждается в создании формальных правил и неформальных институтов, применении правовых механизмов, сознательности и ментальных особенностей населения. Рассмотрено содержание современной институциональной системы трансформации, включающей институциональноправовую, институционально-экономическую и институционально-технологическую системы. Проведена систематизация классификационных признаков: содержание, основные задачи и результаты функционирования подсистем институциональной системы трансформации. Эффективность действующей системы рассмотрена на примере выявления влияния и взаимосвязи всех ее подсистем. Трансформационные изменения влияют на бизнес-среду и приводят к укреплению правовой базы и системы прав собственности, снижению бюрократии и усилению конкуренции. Успех любых усилий по ослаблению влияния неэффективных институтов зависит, прежде всего, от того, насколько быстро можно заменить существующие государственные институты восточноевропейских стран на более надежные и независимые институты. Применение междисциплинарного подхода способствует углубленному изучению движущих сил проведения реформ и может использоваться для определения сценариев будущего развития стран Восточной Европы. правила.

Ключевые слова: трансформация, бизнес отношения, институты, формальные и неформальные

JEL Classification: M20, M21, P48. 